\title{
TEST OF BLOOD DISEASE BACTERIUM (BDB) TRANSMISSION BY POTENTIAL INSECT VECTORS
}

\author{
Betty Sahetapy $^{1}$, Nina Maryana ${ }^{2}$, Syafrida Manuwoto ${ }^{2}$, Kikin H. Mutaqin ${ }^{2}$, \& Fransina Latumahina ${ }^{1}$ \\ ${ }^{1}$ Faculty of Agriculture, Pattimura University, Indonesia \\ Jl. Ir. M. Putuhena. Poka Ambon 97233 \\ ${ }^{2}$ Faculty of Agriculture, IPB University, Indonesia \\ Jl. Kamper Kampus IPB Dramaga Bogor 16680 \\ E-mail: fransina.latumahina@yahoo.com
}

Manuscript received: 3 February 2020. Revision accepted : 10 March 2020

\begin{abstract}
Test of blood disease bacterium (BDB) transmission by potential insect vectors. Blood disease bacterium (BDB) is one of the important diseases in banana and a major obstacle in developing and increasing banana production in Indonesia. The purpose of this study was to prove the ability of the Drosophilidae insect as a vector in transmitting BDB. The research was conducted at the Insect Biosystematics Laboratory and Plant Bacteriology Laboratory, Department of Plant Protection, Faculty of Agriculture, IPB University. Drosophilidae insects were taken from the field and then reared in laboratory by being fed with ripe bananas to obtain offspring that are free from diseases or pathogens. Imago of the Drosophilidae from rearing was fed by inoculum sources which was infected banana, then inoculated into healthy plants. The plants used were healthy and flowering, heliconia. The results showed that the Drosophilidae insects were able to transmit BDB to heliconia plants that showed symptoms, brownish flower colors and falling flower crowns. Detection of BDB isolated from flower parts and the inside parts of the insects used in transmission test using the PCR method showed positive results.
\end{abstract}

Key words: Drosophilidae, heliconia, transmission test, vector

\section{INTRODUCTION}

Blood disease bacterium (BDB) is one of the important diseases in banana plants and a major obstacle in developing and increasing banana production in Indonesia. (Hadiwiyono, 2011). Transmission of BDB by insects has been reported by several researchers. Pathogens can be transmitted by insects vector from one plant to another after going through: 1) the acquisition feeding period, which is the time needed by the vector to eat on the plant until it gets a pathogen; 2) the inoculation feeding period, i.e. the time needed by the vector to eat in healthy plants until they can transmit pathogens; and 3) retention period, i.e. interval of time vectors can still transmit pathogens (Wijaya, 2007). Furthermore, the accuracy of the vector is added to thrill the stylet on the part of the diseased plant and the proportion of the infective vector influences the rate of disease transmission (Dietzgen et al., 2016). In pathogens that are persistent there is a latent period that is the time needed by the pathogen to be in the vector body until it can be transmitted (Montong \& Salaki, 2019). Persistent pathogens are circulative in the vector body, that is, if the pathogen enters through the stylet into the digestive tract, then together with protein, fat and other elements enter the blood through the digestive tract walls in the mesenteron, then carried by blood flow to the salivary glands and excreted back through the stylet (Dietzgen et al., 2016). Insects reported so far are still potential vectors and there were no specific reports regarding vector insects from BDB. In this study, the insects that possitively identified and detected for the presence of BDB inside and outside of the body was suspected to have the potential in transmitting BDB pathogens (Mairawita et al., 2012). To prove this, a BDB transmission test was carried out using the Drosophilidae insect as one of the potential vectors.

\section{MATERIALS AND METHODS}

Research Site. This research was conducted at the Insect Biosystematics Laboratory and Bacteriology Laboratory, Department of Plant Protection, Faculty of Agriculture, IPB University.

Drosophilidae Maintenance. Drosophilla flies used in this transmission tests was collected from the banana 
plantations around Dramaga, Bogor. The flies were catched, maintained, and reared. Rearing of Drosophilla flies in the laboratory was carried out to produce second generation, the offspring that were free of BDB.

Test Plant Preparation. The test plants used in this research were banana (heliconia) which have flowered and were 5 months-old. These heliconia plants were maintained in polybags $(25 \times 25 \mathrm{~cm})$. The growing media wasa mixture of soil and manure with a ratio of $2: 1$. The test plants were kept in large cages of $150 \times 40 \times$ $60 \mathrm{~cm}$ and raised to produce flowers (Figure 1). Heliconia plants were used as test plants because heliconia and bananas belong to family Musacea.

Inoculum Preparation. The inoculum source was bananas infected by blood disease bacteria, which was collected from BDB endemic areas in Aceh and the isolates that were derived from banana (Figure 2A). Isolation of $\mathrm{BDB}$ from diseased bananas was conducted by cut the banana into pieces, then disinfected with sodium hypochlorite solution for $5 \mathrm{~min}$ and rinsed 4 times with sterile water to remove residual sodium hypochlorite. This tissue then crushed and added with $10 \mathrm{~mL}$ of sterile water and gradually diluted 5 times. After that, the bacterial suspension was streak on the prepared Tripheny tetrazolium chloride (TZC) media. Observation of the characteristics of BDB colonies on TZC media was carried out after 48-72 h. The BDB colony is round with a size of $1-4 \mathrm{~mm}$, where the middle parts of the colony are red and the edges are clear. Another characteristic observed was that the colonies tended to be sticky to the surface of the medium so it was rather difficult to remove using an ose needle. In addition, new colonies form on the third day after they are grown at room temperature. This is consistent with the BDB character reported by Mairawita et al. (2012). These pure bacterial colonies were transferred to sucrose peptone agar (SPA) media and incubated for $1-2 \mathrm{~d}$ at $28^{\circ} \mathrm{C}$ (Figure 2B) and then applied to ripe bananas that would be used as feed for Drosophilidae as vector insects in transmission tests (Figure 2C).

\section{BDB Transmission Test Uses Drosophilidae} Insects. The Drosophilidae flies that are used as an infective insect agent are obtained from

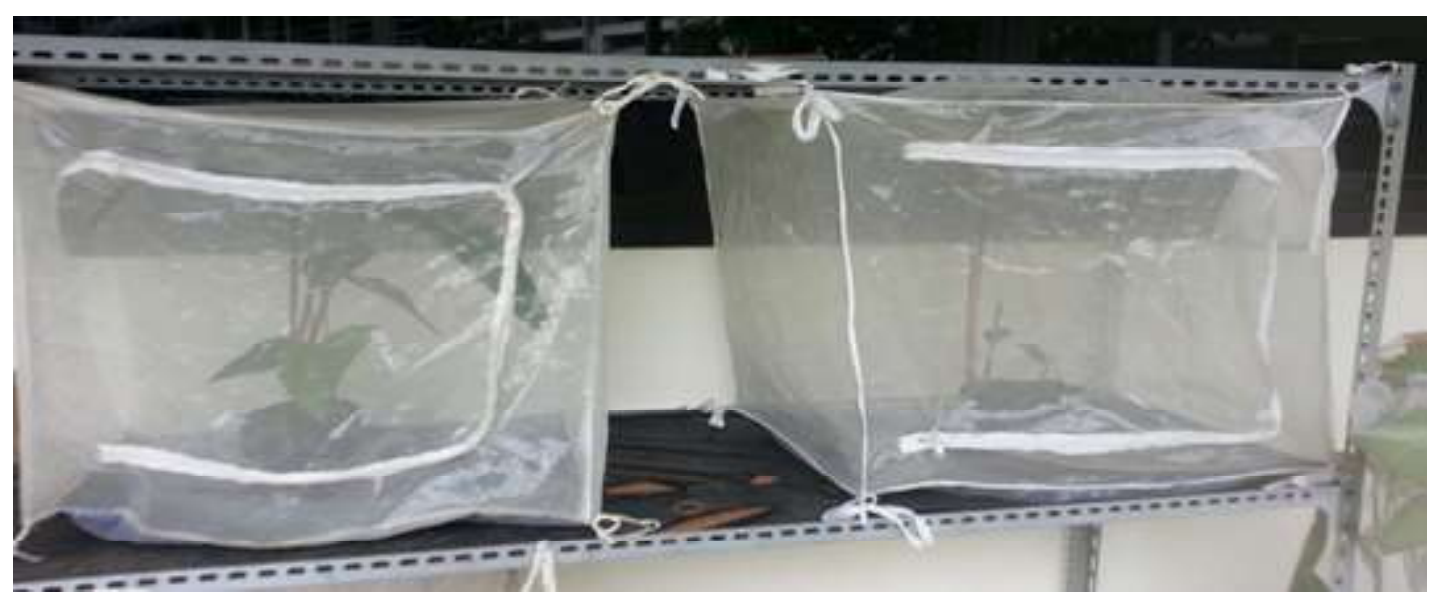

Figure 1. Confinement containing heliconia plants used as test plants.
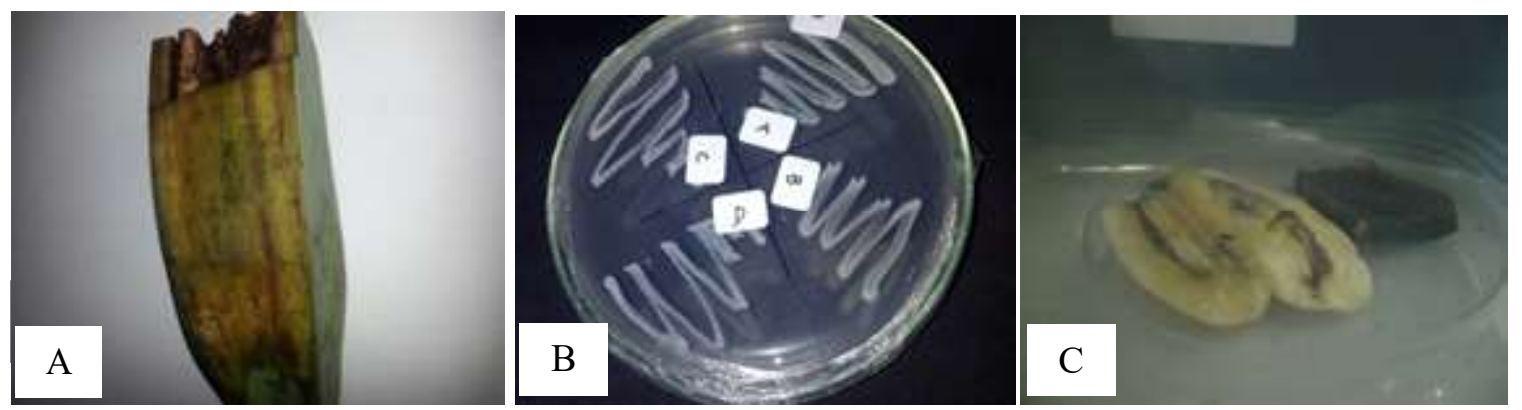

Figure 2. Source of BDB inoculum. (A) Banana infected BDB; (B) BDB isolates on SPA media; (C) Banana smeared with BDB isolates . 
the imago stage after the insects were fasted for $6 \mathrm{~h}$ (Figure 3A-B). After that, it is allowed to carry out the acquisition feeding period (feeding at the source of the inoculum) for $4 \mathrm{~d}$. After going through the acquisition feeding period, the flies are transferred into the heliconia test plants that have been prepared to carry out the latent period as well as the inoculation feeding period for $4 \mathrm{~d}$ (Figure 4). For this transmission test, the number of each test insect being used is 1, 3, 5, 7 and 9 insects/ plants. The control plants used the flies that were given the acquisition feeding period on healthy bananas, with the acquisition period, latent period and the inoculation period as the same as the other treatments.

Transmission test was carried out to determine the role of Drosophilidae as a vector in transmitting BDB bacteria to banana plants and to obtain information regarding the minimum number of vectors to transmit blood diseases. The variables used in this transmission test were the occurrence of the disease and the incubation period. After going through the inoculation feeding period, the infective insect was removed from the cage and isolated for the presence of BDB both of the outside and the inside of the body. The method of isolation was abased on Wijaya et al. (2010).
Detection of BDB. The presence of BDB infection in the inoculated plants was detected using PCR. The bacteria was isolated from flower, because it is the location of the transmission treatments. The infective insects for transmission were also isolated and then detected using the PCR method.

DNA Isolation Procedure. Isolation of bacterial DNA was carried out using the Genomic DNA Mini Kit Geneaid ${ }^{\mathrm{TM}}$ method for isolating bananas, Drosophilidae, and flowers that had been purified from the transmission test results. Bacterial isolates were taken in amount of $5 \mu \mathrm{L}$ plus RBC Lysis Buffer in amount of $900 \mu \mathrm{L}$ and stirred until homogeneous. Incubated at room temperature for $10 \mathrm{~min}$. Put in a Centrifuge at 12,000 $\mathrm{rpm}$ for $5 \mathrm{~min}$. Afterwards, the supernatant was removed. Then, $100 \mu \mathrm{L}$ RBC Lysis Buffer was added to the sample, and re-suspended. After that, $200 \mu \mathrm{L}$ of GB Lysis Buffer was added and gently turned to homogeneous. The suspension then incubated at $60{ }^{\circ} \mathrm{C}$ for $10 \mathrm{~min}$. During incubation, once every $3 \mathrm{~min}$ the tubes were stirred until homogeneous. The $200 \mu \mathrm{L}$ absolute ethanol were added and vortexed for 10 seconds. The sample (supernatant) was moved to the

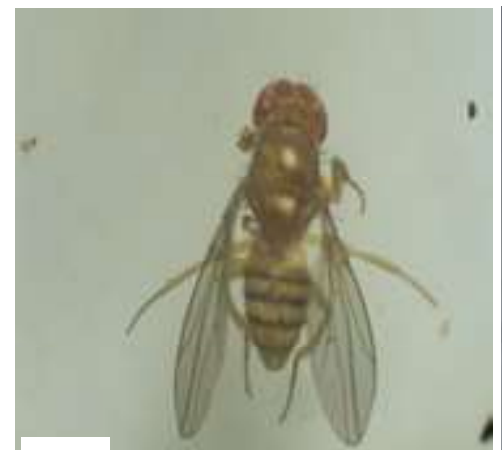

A

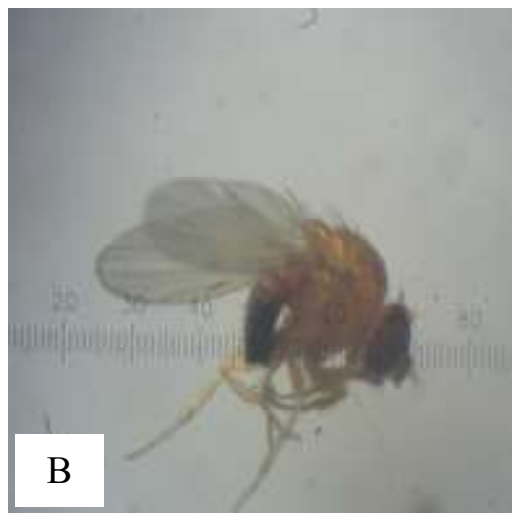

Figure 3. Imago insect of Drosophilidae. (A) Dorsal; (B) Dorsal lateral.

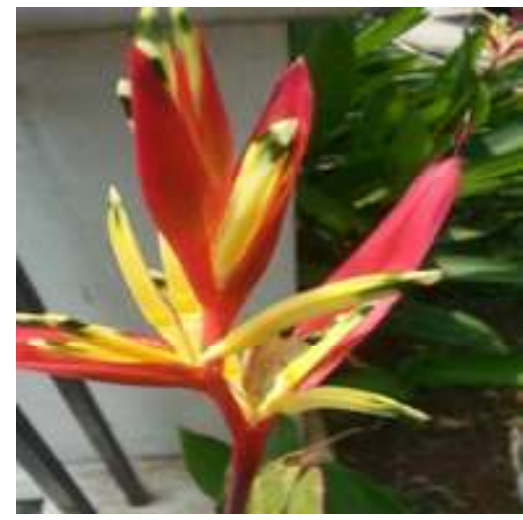

Figure 4. Heliconia plant used in the BDB Transmission test. 
GD column. and centrifuge at $12,000 \mathrm{rpm}$ for 5 minutes, then GD column was moved to the new collection tube. Washed by adding $400 \mu \mathrm{l}$ of W1 buffer. Centrifuged at $12,000 \mathrm{rpm}$ for $30 \mathrm{~s}$. Washed again, by adding $600 \mu \mathrm{L}$ wash buffer. Centrifuged at 12,000 rpm for $30 \mathrm{~s}$. Centrifuged at 12,000 rpm for $3 \mathrm{~min}$. The GD column was transferred to a $1.5 \mathrm{~mL}$ tube. Add an elution buffer in amount of $100 \mu \mathrm{L}$. Incubated at room temperature for $3 \mathrm{~min}$. Centrifuged at 10,000 rpm for $30 \mathrm{~s}$. Samples are stored at $-20^{\circ} \mathrm{C}$.

DNAAmplification Using PCR. Gene fragments were amplified by PCR using primers 759 R (5'GTCGCCGTCAACTCACTTTCC-3') and 760 F (5'GTCGCCGTCAGCAATGCGGAAT CG-3') (Sagar et al.,2014). The DNA amplification process was carried out with an initial denaturation process at a temperature of $94{ }^{\circ} \mathrm{C}$ for $3 \mathrm{~min}$. Denaturation in the cycle was carried out at a temperature of $94{ }^{\circ} \mathrm{C}$ for $15 \mathrm{~s}$, annealed at $57^{\circ} \mathrm{C}$ for $30 \mathrm{~s}$, extension at $72^{\circ} \mathrm{C}$ for $30 \mathrm{~s}$, final elongation at $72{ }^{\circ} \mathrm{C}$ for $10 \mathrm{~min}$ to avoid the presence of DNA that has not been fully amplified. The cycle was done 35 times. PCR results can be stored at $4{ }^{\circ} \mathrm{C}$.

Electrophoresis. The results of DNA amplification were separated based on the size of the base pair by electrophoresis technique, which used $1.5 \%$ agarose gel in a TAE buffer $1 \mathrm{X}$ and added $5 \mu \mathrm{L}$ GelRed per each $50 \mathrm{~mL}$ agarose. Agarose gel solution is poured into a mold to make a well of a certain size. A total of $20 \mu \mathrm{L}$ of PCR results were taken carefully, placed in a gel pit. As a standard molecule, a one kb ladder marker is used. Electrophoresis is run with a potential difference of $100 \mathrm{~V}$ for about $30 \mathrm{~min}$. Observation of DNA bands was carried out under UV light and documented.

\section{RESULTS AND DISCUSSION}

\section{BDB Transmission Test on Heliconia Using} Drosophilidae Insects. Drosophilidae is one of the insects that have been tested (others are Tephritidae and Muscidae) for the presence of BDB bacteria, BDB is also found in the insect's body through isolation (Sahetapy et al., 2019). The sources of inoculum to be infected to the insects are diseased ripe bananas taken from the field and healthy ripe bananas that are smeared with BDB isolate. During the acquisition period, in the confinement fed with diseased banana, the Drosophilidae flies did not survive within 1 day and the flies died so that the flies cannot be used for the treatment. This is because, the flies are normally attracted to the odor produced by the fruit or flowers. Suggests that, whilst the banana is diseased, the fruit was not ripe and the fruit surface is rough, so that the flies cannot absorb the substances contained in the banana. This in fact is in-line to the opinion which states that Drosophila has been known as fruit flies in which a characteristic of the ripe fruit or rotted fruit (Opina et al. 2007). Drosophilla takes material from the rotted Rafflesia patma flowers and is possible to place their eggs in the soft parts of flowers for the growth of their larvae (Antonacci et al., 2017). On the other hand, in the confinement fed with ripe bananas and smeared with BDB isolates, the insect survived during the acquisition period. These flies were used for the transmission test.

Disease Incidence and Incubation Period. BDB transmission test using the insect vector Drosophilidae which was fed for acquisition period, the latent period, and the inoculation feeding period for $4 \mathrm{~d}$ showed positive results (BDB is transmitted) except for treatment with 1 insect and in the control treatment.

The incubation period for the bacteria that causes BDB disease ranges from 31.3 to $79.0 \mathrm{~d}$ (Table 1). This shows the more insects are infected, the more pathogens are transmitted into the plant tissue, causing shorter incubation period. Concentration of pathogens in the plant system is one of the factors that determine the success of transmission of causes of disease in plants. The rate of spread of disease in natural conditions depends on the density of the vector population, the number of bacterial inoculums in plants, the length of the feeding period of acquisition and the length of the inoculation period (Wijaya et al., 2010).

Disease Symptoms Observed in the Test Plants. The first part of the plant showing symptoms is the flower, because inoculation is done on the flower (Mairawita et al., 2012). When the transmission test is carried out, the parts of the flower and the insect are covered so as not to be disturbed by other insects. The obvious symptoms are that the flower changes color to brown and the flower crown begins to fall. Flowers show symptoms first because the nectar is ingested by the insects and its saliva is already containing bacteria and therefore transmits the bacteria to the flowers. This is consistent with the results of a research which shows that inoculation of BDB suspensions in banana flowers can also cause symptoms of the disease. While the symptoms that appear on other parts of the plant are quite long, is because the transmission takes place naturally which is done with the help of insects (Taufik, 2010). Symptoms that were observed in treated plants, shows leaf edges necrosis, leaf yellowing and wilting 
(Latumahina et al., 2015). The process of necrosis begins with the transmission of flower tissue by pathogens through the mouth of the insect while absorbing the surface of the flower. The activities carried out by the insect cause injury to facilitate pathogens into plant tissue. The presence of relatively large amounts of pathogens can cause symptoms of chlorosis and even the occurrence of necrosis (Stulberg et al., 2015).

BDB Isolation and Detection Using PCR. Transmission test results show that the insect Drosophilidae is able to transmit pathogens to the flower parts of the heliconia plant. The pathogen results of the transmission test is confirmed to be BDB bacteria (Figure 5). The isolatation of the BDB was also done to the Drosophilidae insect as a vector and was found as the same isolate. The result shows that BDB bacteria was found in the insect's body part that was crushed, while in the body that is washed with water the bacteria was not found (Figure 6).

Visualization of PCR product on the plant and insect parts tested is shown in Figure 6. Flowers and insects from the transmission test results showed positive PCR results (Table 2). DNA samples came from banana flowers in treatments using 7 and 9 tails Drosophilidae. Positive results were also obtained for the Drosophilidae insect used in the transmission test. The results of bacterial DNA amplification with Ralstonia solanacearum primer $759 \mathrm{~F}$ and $760 \mathrm{R}$ showed a specific band of $280 \mathrm{bp}$ (Figure 7).

Table 1. Disease incidence and the incubation period in insect transmission tests

\begin{tabular}{|c|c|c|}
\hline $\begin{array}{c}\text { Number of insects in each } \\
\text { confinement }\end{array}$ & $\begin{array}{l}\text { Disease incidence* on Heliconia plant } \\
\text { (Symptomatic plants/replication) }\end{array}$ & Incubation period ${ }^{* *}(\mathrm{~d})$ \\
\hline Control (healthy plant with no insect) & $\begin{array}{c}0 / 3 \\
\text { (0 symptomatic plant from } 3 \text { replications) }\end{array}$ & - \\
\hline 1 (healthy plant with 1 insect) & $\begin{array}{c}0 / 3 \\
\text { (0 symptomatic plant from } 3 \text { replications) }\end{array}$ & - \\
\hline 3 (healthy plant with 3 insects) & $\begin{array}{c}2 / 3 \\
\text { (2 symptomatic plant from } 3 \text { replications) }\end{array}$ & 79.0 \\
\hline 5 (healthy plant with 5 insects) & $\begin{array}{c}2 / 3 \\
\text { (2 symptomatic plant from } 3 \text { replications) }\end{array}$ & 71.0 \\
\hline 7 (healthy plant with 7 insects) & $\begin{array}{c}2 / 3 \\
\text { (0 symptomatic plant from } 3 \text { replications) }\end{array}$ & 50.5 \\
\hline 9 (healthy plant with 9 insects) & $\begin{array}{c}2 / 3 \\
\text { (0 symptomatic plant from } 3 \text { replications) }\end{array}$ & 31.3 \\
\hline
\end{tabular}

* Disease incidence is number of symptomatic heliconia plants divided by number of replication (3). ** Number of days from treatment given until the symptom appear. (-): no transmission.
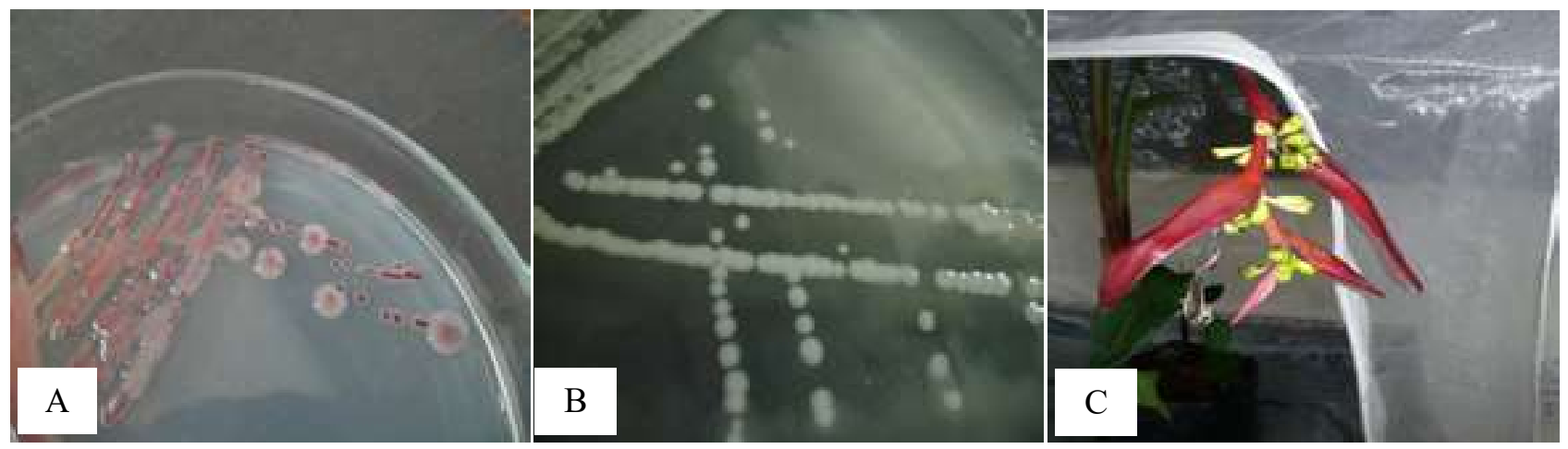

Figure 5. BDB isolates originating from the results of transmission tests. (A) on TZC media; (B) on SPA media; (C) Heliconia flowers on transmission test results. 


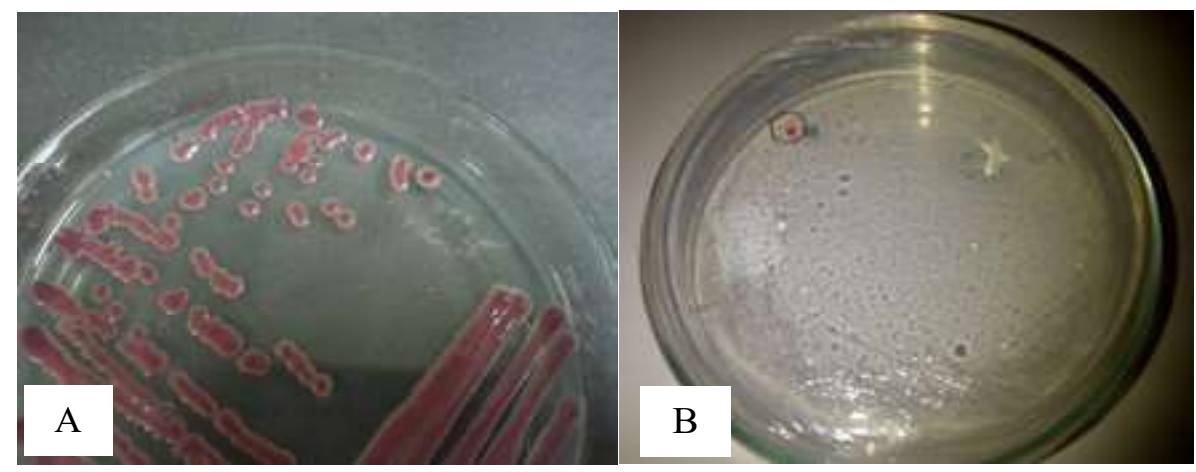

Figure 6. BDB isolates a result of transmission test on TZC media. (A) Inner insect's body; (B) Washed insect.

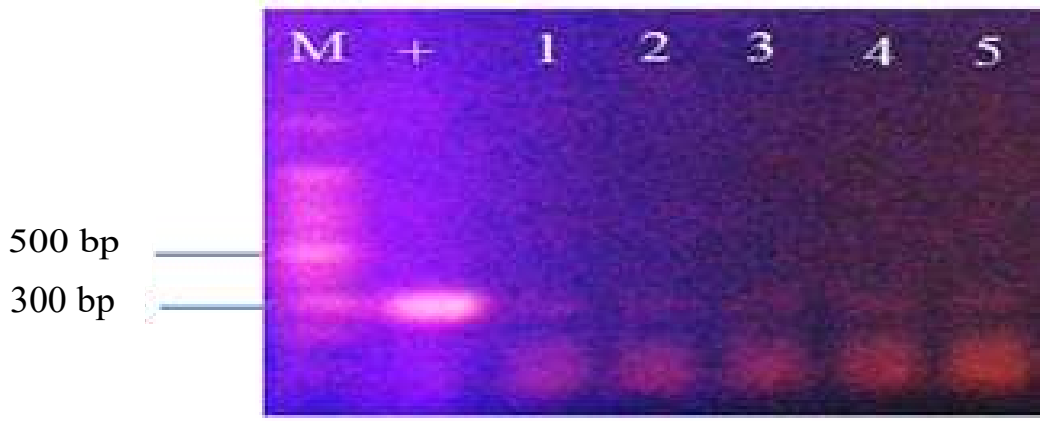

Figure 7. Visualization of BDB DNA from PCR using 759F and 760R primers. $(\mathrm{M}=$ marker $100 \mathrm{bp},+=$ positive control of Ralstonia solanacearum, 1 = Banana fruit (BFR), 2 = Banana flower 1 (BFL1), 3 = Banana flower 2 (BFL2), 4 = Grenn insect 1 (GI1), $5=$ Green insect 2 (GI2).

Table 2. PCR Test with primer 759F and 760R on several isolates of insect origin

\begin{tabular}{|c|c|c|c|c|c|}
\hline \multirow{2}{*}{ No. } & \multirow{2}{*}{ Isolate code } & \multicolumn{2}{|c|}{ Origin of isolates } & \multirow{2}{*}{ PCR results } & \multirow{2}{*}{ Information } \\
\hline & & Order & Family & & \\
\hline 1 & BFR & Banana fruit & Musaceae & + & Not perform \\
\hline 2 & BFL1 & Banana flower & Musaceae & + & Transmission test \\
\hline 3 & BFL2 & Banana flower & Musaceae & + & Transmission test \\
\hline 4 & GI1 & Grind insect & - & + & Transmission test \\
\hline 5 & GI2 & Grind insect & - & + & Transmission test \\
\hline
\end{tabular}

\section{CONCLUSION}

The incubation period for the bacteria that causes BDB disease ranges from 31.0 to 79.0 days. Drosophilidae able to transmit the pathogen BDB to healthy heliconia plants. Symptoms that appear in transmission tests are very slow because transmission occurs naturally with the intermediary of the insect. Detection of the presence of BDB by molecular method showed a band at a size of $280 \mathrm{bp}$ in both plant and insect.

\section{ACKNOWLEDGMENTS}

Thank you to the IPB University for providing the opportunity to conduct research using laboratory facilities.

\section{REFERENCES}

Antonacci R, Tritto P, Cappucci U, Fanti L, Piacentini L, \& Berloco M. 2017. Drosophilidae monitoring in Apulia (Italy) reveals Drosophila suzukii as one of the four most abundant species. Bull. Insectology. 70(1): 139-146. 
Dietzgen RG, Mann KS, \& Johnson KN. 2016. Plant virus-insect vector interactions: current and potential future research directions. Viruses. 8(303): 1-21.

Hadiwiyono. 2011. Blood bacterial wilt disease of banana: the distribution of pathogen in infected plant, symptoms, and potentiality of diseased tissues as source of infective inoculums. Nusantara Biosci. 3(3): 112-117.

Latumahina F, Borovanska M, Musyafa, Sumardi, Putra NS, \& Janda M. 2015. Ants of Ambon Islanddiversity survey and checklist. ZooKeys. 472: 4357.

Mairawita, Habazar T, Hasyim A, Nazir N, \& Suswati. 2012. Potensi serangga pengunjung bunga sebagai vektor penyakit darah bakteri (Ralstonia solanacearum Phylotipe IV) pada pisang di Sumatera Barat. JEI. 9(1): 38-47.

Montong VB \& Salaki CL. 2019. Serangga pengunjung bunga pisang kepok di Kabupaten Minahasa Selatan sebagai pembawa Ralstonia solanacearum Filotipe IV (penyebab penyakit darah pisang). Jurnal ENFiT. 1(1): 17-28.

Opina N, Tavner F, Hollway G, Wang JF, Li TH, Maghirang R, Fegan M, Hayward AC, Krishnapillai V, Hong WF, Holloway BW, \& Timmis JN. 1997. A novel method for development of species and strain-specific DNA probes and PCR primers for identifying Burkholderia solanacearum (formerly Pseudomonas solanacearum). Asia Pac. J. Mol. Biol. Biotechnol. 5(1): 19-30.
Sagar V, Gurjar MS, Arjunan J, Bakade RR, Chakrabarti SK, Arora RK, \& Sharma S. 2014. Phylotype analysis of Ralstonia solanacearum strains causing potato bacterial wilt in Karnataka in India. Afr. J. Microbiol. Res. 8(12): 1277-1281.

Sahetapy B, Uluputty MR, \& Naibu L. 2019. Identifikasi lalat buah (Bactrocera spp.) asal tanaman cabai (Capsicum annuum L.) dan belimbing (Averrhoa carambola L.) di Kecamatan Salahutu Kabupaten Maluku Tengah. Jurnal Agrikultura. 30(2): 63-74.

Stulberg MJ, Shao J, \& Huang Q. 2015. A multiplex PCR assay to detect and differentiate select agent strains of Ralstonia solanacearum. Plant Dis. 99: 333-341.

Wijaya IN. 2007. Penularan penyakit CVPD (Citrus Vein Phloem Degeneration) oleh Diaphorina citri Kuwayama (Homoptera: Psyllidae) pada tanaman jeruk siam. Agritrop. 26(4): 140-146.

Wijaya IN, Adiartayasa W, Sritamin M, \& Yuliadhi KA. 2010. Dinamika populasi Diaphorina citri Kuwayama (Homoptera: Psyllidae) dan deteksi CVPD dengan teknik PCR. JEI. 7(2): 78-87. 